\title{
TRADING CARBON DIOXIDE ON THE EUROPEAN CABON MARKET USING THE EU ETS PLATFORM
}

\author{
Florin Sebastian Duma \\ Ioan Alin Nistor ${ }^{2}$
}

\begin{abstract}
The Carbon Market came with the signing of the Kyoto Protocol and aims to facilitate obtaining financing to purchase the necessary technology to reduce emissions of greenhouse gases, but not only that. The "goods" which are the object of trading on this market are the tons of carbon dioxide which are not emitted into the atmosphere. For trading these goods the EU-ETS system was created. This paper aims to analyze the implications of this new market and all the transactions it will generate in this New Europe.
\end{abstract}

Keywords: EU ETS Market, Kyoto protocol, Trading

JEL Codes: G12, G15, G18.

\section{Introduction}

Trading carbon dioxide emissions is a new concept that at first look, might sound odd. But this new concept turns carbon dioxide emissions into an asset that one can sell and buy. The aim is not the capital gain that an investor or a speculator might obtain, but the best way to regulate, stimulate the companies that during their production pay attention to the environment and disincurage the companies that cause pollution.

\section{Literature review}

Frank Convery, Denny Ellerman, and Christian De Perthuis in the interim report of the " The European Carbon Market in Action: Lessons from the First Trading Period" talk about the „European Union Emissions Trading Scheme (EU ETS) as the largest greenhouse gas market ever established. The European Union is leading the world's first effort to mobilize market forces to tackle climate change". This statement made at the MIT Joint Program on the Science and Policy of Global Change" states the importance of this new concept. They also talk about the future „Geographical and sectoral extension of the cap" giving the sizeable dimensions that the concept can become.

Gutbrod, Sitnikov and Pike-Biegunska in their book "Trading in air: mitigating climate change through the carbon markets", also mention that "Carbon trading lies at the center of global climate policy today. A web of domestic and international carbon markets has emerged around the world, representing a powerful regulatory and market force. These markets have the potential to yield significant environmental benefits while offering financial opportunities."

Also "The Monthly Bulletin of the European Carbon Market" presents in their issues the size and potential of this market as well as the benefits of controlling and regulating a market with the help of a free market where the demand and offer have a powerful word to say.

Our paper is also looking at the implications of this new market and the dimensions that can reach both from the transactions point of view as well as benefit for the climate.

\footnotetext{
1 "Babeş-Bolyai" University of Cluj-Napoca, e-mail: fduma@euro.ubbcluj.ro

2 "Babeş-Bolyai" University of Cluj-Napoca, e-mail: ioan.nistor@tbs.ubbcluj.ro
} 


\section{The Kyoto Protocol}

In 1997 in Kyoto (Japan) was negotiated the International Agreement on environmental issues which would completely change the approach to problems caused by pollution and climate changes. This, known as the Kyoto Protocol (KP), aimed at limiting and reducing emissions of greenhouse gases. The Agreement provides for industrialized countries (37 countries and the EU) an average 5.2\% reduction in pollutant emissions for the period 2008-2012 taking as the reference year 1990 (EU assumed an $8 \%$ reduction).

Although the Protocol was adopted in December 1997, it entered into force only in February 2005. The reduction percentage of greenhouse gases emissions that each country has registered differs from case to case, although the EU has initially proposed a reduction of $15 \%$ undifferentiated from 1990. Moreover, unfortunately not all countries have ratified (the most notable example being the U.S., who is also responsible for other about $40 \%$ of total emissions of greenhouse gases (GHG).

Greenhouse gases defined by the KP are shown in the table below:

Table no. 1

Greenhouse gases defined by the Kyoto Protocol

\begin{tabular}{|l|l|}
\hline GHG (Greenhouse gas) & Formula \\
\hline Carbondioxide & $\mathrm{CO} 2$ \\
\hline Methane & $\mathrm{CH} 4$ \\
\hline Nitrous Oxide & $\mathrm{N} 2 \mathrm{O}$ \\
\hline (Hydrofluorocarbons) & HFCs \\
\hline (Perfluorocarbons) & PFCs \\
\hline Sulphur Hexafluoride & SF6 \\
\hline
\end{tabular}

Source: Kyoto Protocol, Annex A, http://unfccc.int/resource/docs/convkp/kpeng.pdf

In the text of the Kyoto Protocol are also stated the sources of greenhouse gases, i.e. areas of pollution, among which are: energy, fuel combustion, manufacturing industries and construction, transport, mineral products, chemical industry, metal production etc.

The Kyoto Protocol provides countries that have pledged to reduce greenhouse gases, mechanisms and tools to help them meet these goals, and this is done by standardizing the form of certificates and the allocations of emission reductions of greenhouse gases, each equivalent to one ton of carbon dioxide and by creating an organized market which would be able to trade them.

Mechanisms that are provided by the Kyoto Protocol to help signatory countries to accomplish these goals (in a cost-effective way) are:

1. Emissions trading (which would become the carbon market)

2. Clean Development Mechanism (CDM)

3. Joint Implementation.

The first of the three mechanism instances means actually the creating of a market which is able to trade surplus allowances (called AAU - Assigned amount units) that a country has received under allocated quota and which were not used. Because carbon dioxide is the main greenhouse gas that is subject to these allowances, the market has taken the name of the carbon market.

The CDM is a mechanism by which industrialized countries, who signed the Kyoto Protocol, which invests in projects to reduce emissions in developing countries, receive in exchange tradable emission certificates CER (Certified Emission Reduction). Each CER is equivalent to one ton of carbon dioxide.

The Joint Implementation is a mechanism that refers to projects developed by an industrialized country in another industrialized country, both part of the Kyoto Protocol, in order to reduce emissions of greenhouse gases. In return for this investment and the transfer of technology, 
this will earn certified emission reduction ERUs (Emission Reduction Unit) each equivalent to one ton of carbon dioxide.

These types of emissions reduction certificates (AAUs, CERs and ERUs) are equivalent to one ton of carbon dioxide and can be traded on the "stock market". Thus, was created the effective carbon market in which the traded goods are the "NOT" emitted tons of carbon dioxide in the atmosphere, and vendors are countries or companies that reduce their emissions and the buyers are those who do not fit in the allocated pollution limits.

\section{The birth of the European carbon market}

The idea of a carbon market was generated and driven by adopting the Kyoto Protocol, that industrialized countries have signed to reduce emissions of greenhouse gases in different proportions, taking as reference year 1990. European carbon market actually was born in October 2003, with the entry into force of the European Directive 2003/87/EC which laid down the framework for trading of emission allowances for greenhouse gases.

Various attempts and steps in this direction, more or less successful, were made long before in Europe. Since the Single European Act of 1986, the treaty that founded the European Single Market, the importance of addressing climate change issues at the European community as a whole unit was often highlighted.

This idea was based on at least two strong justifications, namely: one related to the fact that pollution and climate change is a border problem (transcend national border) and another related to cost efficiency.

These concerns prompted the European Commission in 1992 to propose a sole tax on carbon (carbon tax) in the European Communities. As a very bold proposal, the Commission has encountered strong resistance both from states that where challenged by national sovereignty through fiscal intervention, and, of course, from companies and industries directly concerned (Convery F. \& co., 2008). It seems that Europe was not yet ready for it, and in 1997 it was proposed to withdraw the imposing carbon tax. It should be noted that during discussions on the introduction of flat tax on carbon, this was proposed by some of those who opposed it firstly, as an alternative to creating an emissions trading system.

Despite this failure to fight emissions of greenhouse gases, however 1997 brought something special. In this year was negotiated in Japan, Kyoto, the international environmental agreement that would completely change the approach to problems caused by pollution and climate change. Following the Kyoto Protocol, the Commission proposed in 2001 a draft of a trading scheme of greenhouse gases emissions (the Emission Trading Scheme), which after ratification of the Protocol in 2002 and after amendments by the Council and the Parliament, was adopted as a directive: EU-ETS Directive 2003/87/EC.

With the adoption of this Directive things start to accelerate. Basically, the Kyoto Protocol entered in force in early 2005, beginning the first phase of the EU - ETS that will end in 2007. In this pilot phase, the evaluation takes place and the first free allocation of emission allowances (EUAs - European Union Allowances) for each Member State in pursuant with the National Allocation Plans (NAP I), that were prepared in accordance with criteria established by the Commission. These NAPs were evaluated, negotiated and amended by the Commission and finally, free allocations were made at a rate of $95 \%$. At the national level for each pollutant unit there was established a GHG emissions limit and therefore was assigned a corresponding number of allowances.

The operating principle of these instruments is simple. At the end of each year, the polluter must deliver a number of certificates equal to the total emissions. If certificates remain, he can keep them for years to come or he can sell them to other polluters, national and international, who have exceeded the quota. If the operator does not deliver sufficient allowances to cover as polluted, he will be fined and will have to buy them and give them away anyway. 
The main economic sectors falling under the certificate allocations are: energy, steel industry, production of cement, ceramics and paper.

The second phase covers the period 2008 - 2012, and allocations are made by the new National Allocation Plans (NAP II) analyzed by the Commission to comply with the criteria laid down in Directive EU - ETS; allocations are free, but in a bit smaller proportion (only 90\%), the difference being able to be found through auctions or through joint projects. This phase coincides with the first phase of the Kyoto Protocol, in which commitments to reduce GHG emissions should be carried out by Member States. This also means access to the certificates (credits) from international projects carried out in accordance with Kyoto Protocol mechanisms, such as Clean Development Mechanism or Joint Implementation.

In 2009, Directive 2009/29/EC brought changes to the former one from 2003 and prepared the ground for the third phase, starting in 2013. In this phase, covering the period $2013-2020$, it is aimed at giving up the NAPs, following that allocation of certificates to be made through a centralized system at EU level.

Also, gradually each year there will be less free allocation, with increasing weight on certificates obtained through auctions. More area will be covered in the economic sectors including new areas: petrochemicals, ammonia and aluminum industries.

\section{The European Union Emissions Trading Scheme (EU ETS)}

The possibility of creating a trading system in EU carbon emissions was raised during discussions on the introduction of flat tax on carbon. After giving up the idea of introducing full unique carbon tax, in 1998 the European Commission issued "Climate Change: Towards an EU Post-Kyoto Strategy", which stated that the Community could set up its own internal trading scheme by 2005. As a result, in October 2003, the Directive 2003/87/EC establishing a scheme for greenhouse gas emission allowance trading within the Community came into effect, with trading that started in January 2005.

The EU ETS is a market working on the 'cap and trade' principles, meaning there is a limit (a cap) of the amount of GHG emissions from an operator and according to this they will get emissions allowances which can be traded. If the company manages to pollute less, then it can keep the spare allowances for future needs or can sell this to another operator which has a shortage. But, if by April 30, each year, a company is not able to surrender the number of certificates according to previous year emissions, then must pay a fine of 100 euro for each missing certificate and also has to buy them. The main goal of the EU ETS is to facilitate the transfer of allowances between the operators.

The EU ETS is the biggest international scheme for the trading of greenhouse gas emission allowances and covers around 11,000 power stations and industrial plants in 30 countries, 27 from EU plus Norway, Iceland and Liechtenstein (European Commission, DG - Clime, 2010).

The EU ETS has an electronic system who is keeping the record of the emission certificates for the entire member states trough the national registries.

The EU ETS established three phases:

1. Pilot phase from $2005-2007$;

2. Phase II (or Kyoto Phase) from 2008 - 2012;

3. Phase III from $2013-2020$.

For the first two phases the permits were allocated for free, according to the National Allocation Plans (only a very small part was allocated for auction - 5\% in phase I and 10\% in phase II). From the third phase fewer permits will be allocated for free and is expected that about half of them to be auctioned. Moreover, after 2013, is planned that the cap for allowances will be decreased each year by $1.74 \%$ until 2020 . 
In order to facilitate the transactions with GHG emissions on the EU-ETS were created special certificates, called allowances - EUA. The most important emissions certificates which are traded on the markets are presented in the table no.2.

Table no. 2

Emissions certificates traded on the markets

\begin{tabular}{|ll|l|}
\hline $\begin{array}{l}\text { EUA (European } \\
\text { Allowances) }\end{array}$ & Union & $\begin{array}{l}\text { The trade unit from EU ETS. One EUA is equal to one tone } \\
\text { of CO2 equivalent. }\end{array}$ \\
\hline $\begin{array}{l}\text { CER (Certified } \\
\text { Reduction) }\end{array}$ & Emission & $\begin{array}{c}\text { CERs are issued for emission reductions from CDM (Clean } \\
\text { Development Mechanism) Projects (green energy). }\end{array}$ \\
\hline $\begin{array}{l}\text { ERU (Emission } \\
\text { Unit) }\end{array}$ & Reduction & $\begin{array}{l}\text { A Kyoto Protocol unit equal to one tone of CO2 equivalent. } \\
\text { ERUs are generated for emission reductions from joint } \\
\text { implementation projects (JI). }\end{array}$ \\
\hline $\begin{array}{l}\text { VER (Verified } \\
\text { Reduction) }\end{array}$ & Emission & $\begin{array}{l}\text { Carbon credits not certified under Kyoto Protocol, but can } \\
\text { be used for compensating carbon emission. }\end{array}$ \\
\hline
\end{tabular}

Source: EU- National Allocation Plans

For trading the emission certificates (EUA, CER, ERU) were created several specialized Stock Exchanges in Europe. Among them, Blue Next in Paris is the most important trading exchange for carbon, offering spot and futures trading with emissions certificates, but also auctions.

The volume of the EUA traded on the exchanges and on the OTC markets was growing fast, each year, with a small decrease in 2010 , as we can see in figure below.

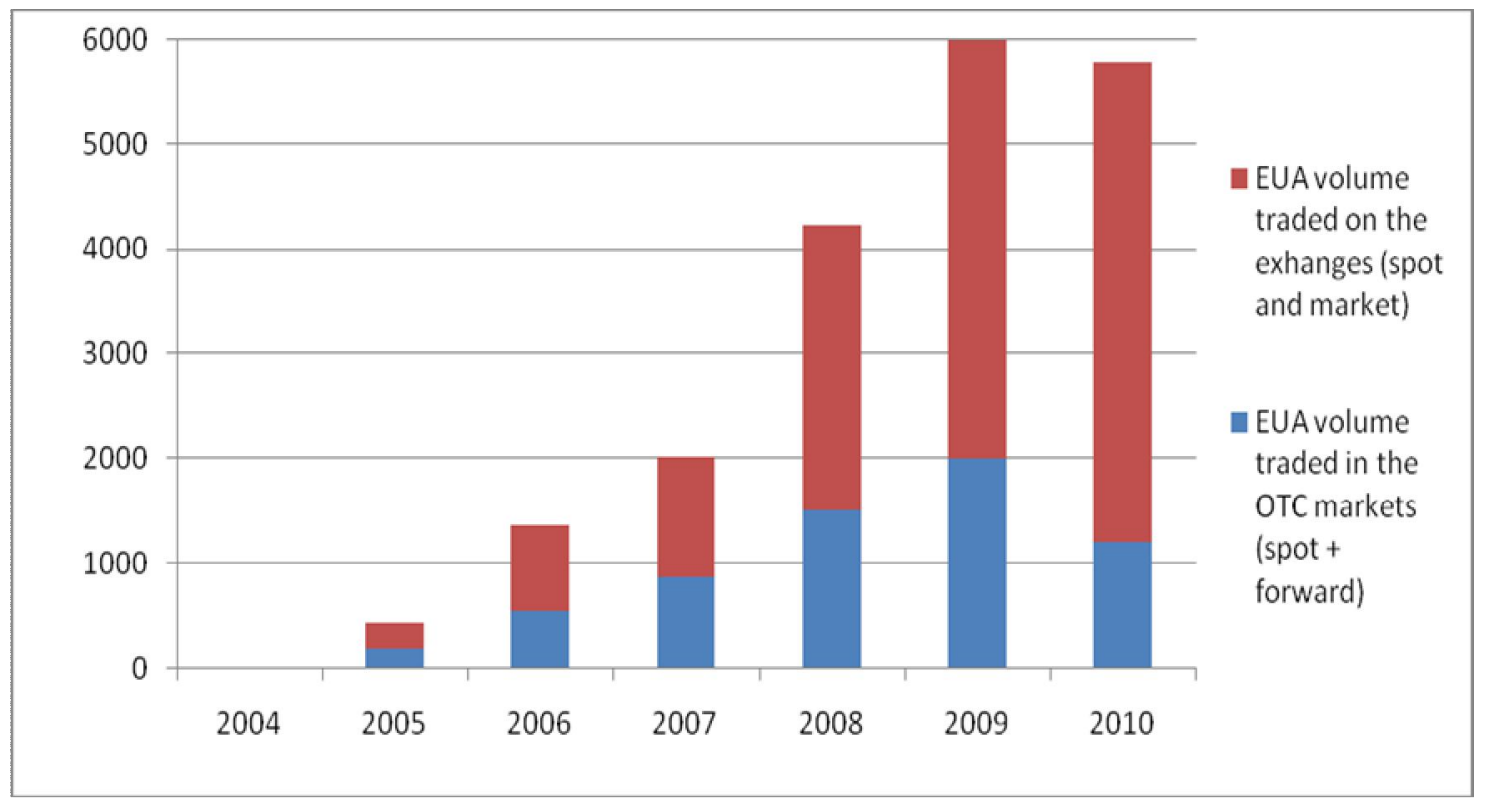

Figure no. 1. - Liquidity on the EUA Market $\left(\mathrm{Mt} \mathrm{CO}_{2} \mathrm{eq}\right)$

Source: Authors' work based on data provided by "Tendances Carbone" issue 5, 2011

\section{Benefits and shortcomings of the EU-ETS}

Creating EU-ETS, Europe made the largest multi-national trading market for emissions, in quite a short period of time. BlueNext Paris is the biggest carbon exchange in the world where companies, states and individuals can easily trade all the main emission certificates under EU-ETS scheme (EUA, CER and ERU). Besides trading, Bluenext offers the possibility for companies or for states to hold auctions there, which is very useful considering the large number of members of this 
Exchange who are potential buyers or sellers. Together with Market, Bluenext even launched an index based on the EUA spot transactions (http:// www.bluenext.eu, http:// www.markit.com).

One of the biggest achievements is that through the EU ETS scheme, Europe has managed to put a price on the carbon dioxide emissions. Actually, the EU ETS cap and trade mechanism can be a 'carrot' for some companies or a 'stick' for some others. As a result we can find economic sectors with surplus of allowances (these can be sold on the exchange market), as well as sectors with deficits (in this case the companies have to buy the missing allowances). This is also valid for the member states, most of them having a surplus of allowances, while some of them having a deficit, as we can see in table bellow (table no.3):

Table no. 3

Emission-to-cap by EU ETS sector and country: difference between distributed
allocations of allowances and verified emissions
\begin{tabular}{|l|l|l|l|l|}
\hline & $\mathbf{2 0 0 8}$ & $\mathbf{2 0 0 9}$ & $\mathbf{2 0 1 0}$ & $\mathbf{2 0 1 1}$ \\
\hline Combustion & -255.7 & -117.1 & -128.1 & -84.2 \\
\hline Oil refining & -1.8 & 7.3 & 14.5 & 14.7 \\
\hline Coking plants & 1.5 & 6.8 & 2.9 & 3.2 \\
\hline Metal ores & 4.3 & 11.0 & 8.8 & 9.0 \\
\hline Steel production & 51.3 & 89.3 & 71.3 & 71.2 \\
\hline Cement & 19.8 & 59.1 & 60.9 & 62.6 \\
\hline Glass & 2.3 & 5.8 & 5.4 & 5.4 \\
\hline Ceramic products & 4.7 & 9.2 & 10.0 & 9.5 \\
\hline Paper & 6.4 & 10.7 & 10.0 & 10.8 \\
\hline Other activities & 0.2 & 4.2 & 1.1 & 2.4 \\
\hline Total (Mt) & $\mathbf{- 1 6 6 . 9}$ & $\mathbf{8 6 . 3}$ & $\mathbf{5 6 . 8}$ & $\mathbf{1 0 4 . 6}$ \\
\hline Germany & -84.5 & -37.5 & -54.5 & -49.7 \\
\hline United Kingdom & -53.1 & -18.1 & -17.7 & 2.6 \\
\hline Italy & -9.5 & 23.4 & 8.5 & 4.9 \\
\hline Poland & -3.3 & 10.6 & 5.8 & 4.1 \\
\hline Spain & -10.3 & 12.8 & 28.8 & 18.0 \\
\hline France & 5.1 & 17.4 & 23.4 & 25.6 \\
\hline Czech Republic & 5.1 & 12.0 & 10.4 & 12.3 \\
\hline The Netherlands & -6.4 & 2.5 & 0.1 & 8.9 \\
\hline Romania & 7.7 & 24.8 & 27.6 & 23.6 \\
\hline Others & -17.6 & 38.4 & 24.4 & 54.3 \\
\hline Total (Mt) & $\mathbf{- 1 6 6 . 9}$ & $\mathbf{8 6 . 3}$ & $\mathbf{5 6 . 8}$ & $\mathbf{1 0 4 . 6}$ \\
\hline Sorce: CITL & - & & \\
\hline
\end{tabular}

Source: CITL, Tendances Carbonne, July 2011

Another important achievement is that the EU ETS made clear for the industries across Europe that polluting is not a right and is not for free and this mechanism is helping Europe to reduce the greenhouse gases emissions according to the targets assumed in the Kyoto Protocol.

\section{Conclusions and perspectives for the EU ETS}

The birth of the European carbon market was not easy at all and is still in development. Though there are a lot of obstacles, due to the permanent improvements, we can appreciate that is a success.

Things improved from the first phase to the second, and we expect to improve more in the third phase of the EU-ETS:

- passing from the first to the second phase, the Commission was reducing the allocations; 
- no more negotiations between the European Commission and the Member States, but NAP II were virtually predetermined by a single forecasting model;

- in the third phase, we expect less free allocations and a progressive move towards auctioning of allowances;

- an option for improving security on EU ETS could be the implementation of one centralized EU registry from 2013 onwards.

Regarding the development of this market, new sectors are expected into the ETS: airlines (from 2012), as well as petrochemicals, ammonia and aluminum industries from the phase III.

On the other hand, some very important questions still remain: should the new entrants buy their allocations, should EUAs be subject of VAT or how can we efficiently solve the security problems on the EU-ETS? Besides this, there are present also some problems of the Encouraging investments in green energy projects is another important benefit of the EU ETS such as: cyberattacks resulting in theft of allowances in several countries (including Romania); internet phishing on the national registries; VAT frauds. Still, we have to give credit to the ,largest greenhouse gas market ever established".

\section{References}

1. Convery F., Ellerman D., De Perthuis C., 2008. The European Carbon Market in Action: Lessons from the First Trading Period. Interim report, MIT Joint Program on the Science and Policy of Global Change, June

2. Gutbrod M., Sitnikov S., Pike-Biegunska E., 2009. Trading in air: mitigating climate change through the carbon markets, Infotropic Media

3. CDC Climate Research, Bluenext, Metnext - Tendances Carbone - The Monthly Bulletin of the European Carbon Market, various numbers

4. Directive 2003/87/EC of the European Parliament and of the Council of 13 October 2003

5. Establishing a scheme for greenhouse gas emission allowance trading within the Community and amending Council Directive 96/61/EC

6. Directive 2009/29/EC of the European Parliament and of the Council of 23 April 2009, amending Directive 2003/87/EC so as to improve and extend the greenhouse gas emission allowance trading scheme of the Community

7. European Environment Agency - "Greenhouse gas emission trends and projections in Europe 2007”, EEA Report No. 5/2007, http://reports.eea.europa.eu/eea_report_2007_5/en

8. European Environment Agency - "Greenhouse gas emission trends and projections in $\begin{array}{llll}\text { Europe 2009”, } & \text { EEA }\end{array}$ http://www.eea.europa.eu/publications/eea_report_2009_9

9. European Environment Agency - "Tracking progress toward Kyoto targets", EEA Report No.7/2010, http://www.eea.europa.eu/publications/progress-towards-kyoto

10. European Environment Agency - "Application of the Emission Trading Directive by EU member states -reporting year 2008), Technical Report No.13/2008, http://www.eea.europa.eu/publications/technical_report_2008_13

11. Matthes, F., Graichen V., Repenning, J. - "The environmental effectiveness and economic efficiency of the European Union Emissions Trading Scheme: Structural aspects of allocation“, Öko-Institut e.V., 2005

12. United Nation, 2008. Kyoto Protocol to the United Nations Framework Convention on Climate Change

13. World Bank, 2011. Carbon Finance, State and Trends of the Carbon Market 2011, Washington, June, available online at http://siteresources.worldbank.org/INTCARBONFINANCE/Resources/State_and_Trends_ Updated_June_2011.pdf 